\title{
Improving the System of the National Qualification Test for Customized Cosmetic Preparation Managers
}

\author{
Ji-yu Hong ${ }^{1}$, Young-Sam Kim ${ }^{2 *}$ \\ ${ }^{1}$ Department of Cosmetics Engineering, Konkuk University, Seoul, Korea \\ ${ }^{2}$ Department of Image Industry, Graduate School of Engineering, Konkuk University, Seoul, Korea
}

\author{
*Corresponding author: Young-Sam Kim, \\ Department of Image Industry, Graduate \\ School of Engineering, Konkuk University, \\ 120 Neungdong-ro, Gwangjin-gu, Seoul \\ 05029, Korea \\ Tel.: +82 24500463 \\ Fax: +82 24056154 \\ Email: gracehelen@konkuk.ac.kr
}

Received June 29, 2020

Revised August 05, 2020

Accepted August 10, 2020

Published September 30, 2020

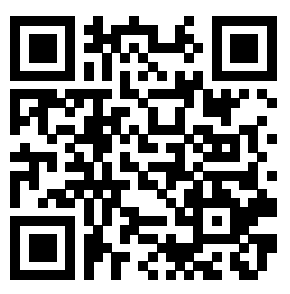

\begin{abstract}
Purpose: To explore the relationship between customized cosmetic preparation managers and beauticians and suggest a way to improve the effectiveness of the current system of the national qualification examination for customized cosmetic preparation managers. Methods: The survey included 131 beauticians who had obtained or were planning to obtain a customized cosmetic preparation manager license. Data were analyzed using SPSS (Statistical Package for Social Science) V.18. Results: They are generally satisfied with the introduction of the national qualification examination for customized cosmetic preparation managers but are not completely satisfied with the manner in which the examination is administered, including how they can improve practical capabilities and whether the test is appropriately evaluated in case there is no performance test, no requirement for applying for the exam, and even no education system. Moreover, they are not satisfied with the current curriculum in general and are unclear about the clear criteria for the range of duties and skills of customized cosmetic preparation managers specified in the curriculum and lack of a course in the curriculum providing actual practice, although there should be one. Conclusion: The test curriculum and method of the current qualification examination for customized cosmetic preparation managers need to be improved in addition to developing the standards of the job skills for prescribing customized cosmetics. This effort to establish the system will build social trust for customized cosmetic preparation managers, enhance the effective value of the license, and help lay the foundation for customized cosmetics businesses to establish in our society.
\end{abstract}

Keywords: Customized cosmetic preparation manager, Esthetician, Job relevance, System of national qualification test, Systemimprovement

\section{Introduction}

미용산업 및 화장품 시장의 새로운 성장 동력이 될 것이라는 전망 하에 2020년 3월 맞춤형화장품 판매업 제도가 본격 시행됨에 따라 화장품 혼합이나 소분 등을 할 수 있는 전문가를 양성하기 위한 맞 춤형화장품조제관리사 국가자격시험제도가 시행되어 이에 대한 피 부미용사의 관심이 커졌다.

맞춤화는 증가하는 소비자의 가치와 더 나은 서비스 만족으로 경 쟁적인 이득을 제공할 수 있다는 장점이 있으며(Simonson, 2005), 특정 소비자의 니즈를 반영하여 제품을 제작하거나 서비스를 제공
하는 것을 의미한다(Pine et al.,1995). 맞춤형화장품조제관리사에 대한 소비자들의 인식이 화장품 제조업자나 화장품처방전문가 다 음으로 피부관리사라는 인식이 있고, 특히 맞춤형화장품 중 판매 자 조언이 가장 필요한 제품으로 기초화장품을 선택하고 있으며, 피 부미용사의 피부관리는 기초화장품을 바르는 것을 포함한다(Lee \& Yoon, 2010)는 것을 감안하면 피부미용사와 맞춤형화장품조제관리 사의 관련성은 매우 높다. 피부 건강상태의 유지는 매우 중요한 요 소이며(Lee \& Hong, 2002), 피부관리실에서는 피부진단을 통해 자 신의 피부타입에 적합한 화장품을 처방 받아 피부문제점을 해결할 수 있는 맞춤 화장품을 구입할 수 있다. 화장품 처방이란 이미 만들 
어진 화장품을 피부 미용 종사자가 고객의 나이와 성별, 성격과 화 장품 선호, 경제력, 헬스컨디션, 피부스킨 스토리와 현재 컨디션 등 고객의 전반적인 라이프스타일을 상담한 후 화장품을 제안하는 것이다(Choi, 2016). 고객의 피부를 유전적요인과 기후 습관 등을 고려해 진단하고(Kim, 2003), 고객 피부에 맞는 화장품을 사용 횟 수, 사용 량, 사용 방법까지 처방하여 판매하는 것이다. 이처럼 화 장품과 관련된 업무 부분은 피부미용사의 직무영역에 포함되어있 다(Jeong, 2012). 화장품 구매자의 소비 추세가 점점 가치지향적으 로 변해가고(Kang \& Hwang, 2007), 이러한 상황에서 피부미용사 들의 맞춤형화장품조제관리사자격증에 대한 활용기대는 매우 높다. 맞춤형화장품이 개인의 피부 특성에 맞는 방법으로 피부를 가꾸는 수단으로써 전문가 조언을 통해 자신의 피부에 적합한 화장품과 원 료 선택이 가능하다는 것이므로, 조제 과정에 피부미용사들의 임상 경험이나 기술적 역량이 더해진다면 강력한 시너지 효과를 발휘할 수 있을 것이다.

첫 시험을 통해 배출된 맞춤형화장품조제관리사는 3000 명에 가 깝지만 제도 도입 취지대로 새로운 일자리 창출과 $\mathrm{K}$-뷰티 혁신 에 이바지할 수 있으리라 낙관하기에는 아직 이르며, 맞춤형화장품 이 화장품업계 발전을 위한 새로운 패러다임이라는 긍정적인 평가 와 더불어 정작 이에 대한 가이드 라인이 발표되지 않아 안전성 문 제 등과 관련한 우려의 목소리도 끊이지 않고 있다. 가격은 외부 에 표시되는 제품 속성 중 하나로 이익창출의 가장 주된 수단이며 (Zeithmal, 1988), 맞춤형화장품 사업의 특성상 제품을 매장에서 직 접 조제하기 때문에 얼굴분석기술을 활용한 뷰티테크 서비스가 강 화되어야(Kim, 2017)하기 때문에, 시설과 장비 및 전문인력 관련 높은 투자비용을 수반하고(Shim \& Choi, 2017) 따라서 개인사업자 에게는 시도 자체가 어려울 수 있다. 식약처에서는 맞춤형화장품 사 업이 중소기업의 독특한 아이디어로 참여하는 취지로 마련된 것이 며, 기존 제품을 혼합하여 다른 새 제품을 만드는 방식으로 고가의 장비를 마련하지 않더라도 맞춤형화장품을 제조하는 아이디어를 활 용할 수 있다고 하였다. 더불어 생산자와 수요자 간의 커뮤니케이션 을 원활하게 하여 소비자 욕구에 부응하는 맞춤생산의 가능성을 높 이는 계기가 되는 것(Ansari \& Mela, 2003)을 기대하였다. 그러나
정작 맞춤형화장품 시범사업이 대기업 위주로 진행이 되었다는 점 은 시사하는 바가 크다.

이와 같이 고무적인 동시에 우려스러운 전망이 함께 제시되는 가 운데, 피부미용 서비스 규모의 증대, 융합 학문의 도입, $\mathrm{K}$-beauty 등의 확산과 같은 다양한 원인으로 미용업계가 더욱 활성화 되고 있 고(Kim, 2019) 피부미용 업계에서도 맞춤형화장품에 대한 관심이 높아지고 있다. 특히 피부관리실을 중심으로 유통되어 왔던 '전문 화장품' 이 피부미용사가 직접 조제한 맞춤형화장품으로 대체될 수 있다는 기대가 높다. 피무관리실 전문화장품이란 피부 관리실에서 만 사용되는 화장품으로, 전문적인 지식을 갖춘 피부관리사가 피부 미용을 위해 사용하는 화장품을 말한다(Kwon \& Kim, 2010). 피부 관리실 피부미용사가에게 관리 서비스를 받을 때 이러한 전문화장 품을 사용하며, 고객은 화장품구입에 있어 구매 편리성이 중요한 요 인(Kim \& Oh, 2018)이란 점을 감안하면, 고객의 자가관리에도 피 부미용사의 상담과 추천에 의해 피부관리실 전문화장품이 사용되므 로 이는 곧 맞춤형화장품의 조제 판매로 확대가 가능한 점을 보여준 다. 물론 소비자가 판단하는 고가 화장품의 기준은 사회 문화적인 속성에 따라 범위가 다르게 해석될 수 있으며(Seo, 2012), 피부관리 실 고객들은 화장품을 구매하고 효과와 성분에 대한 만족도로 재구 매가 이루어진다.

이에 본 연구에서는 피부미용사와 맞춤형화장품조제관리사의 직 무 간의 상호 관련성을 중심으로 현행 맞춤형화장품조제관리사 자 격시험제도 및 시험 교과편성을 고찰해 보고자 하였다. 맞춤형화장 품조제관리사 자격증을 취득하였거나 취득 예정인 피부미용사를 대 상으로 설문조사를 실시하여 그 만족 수준을 파악함과 동시에 합당 한 개선 방향이 무엇인지 탐색해 보고자 하였다. 제도 시행 첫 해 자 격시험 운영상의 많은 시행착오가 예상되며 건전하게 정착되기까 지 상당한 시간이 소요될 것이라는 전망이 나오기도 하였다. 따라서 이러한 제도를 연구하려는 입장에도 많은 한계점이나 문제점이 따 를 것을 예상할 수 있다. 그럼에도 불구하고 본 연구의 성과가 피부 미용사의 전문성 및 실무능력 향상, 자격증 활용도 향상에 기여하는 바가 있기를, 맞춤형화장품조제관리사 자격제도의 안정화 방안을 제시하는 데 기초 자료로 활용될 수 있기를 기대한다.

\section{Table 1. Recognition level of job relatedness of beauticians and customized cosmetic preparation managers with respect}

\begin{tabular}{|c|c|c|}
\hline Questions & Mean & Standard deviation \\
\hline One must have a lot of expertise related to skin care & 4.05 & 0.75 \\
\hline One must be able to serve and manage a diverse customer base & 4.18 & 0.65 \\
\hline One must have adequate experience in the field and working experience & 4.15 & 0.72 \\
\hline One must sufficiently understand the cosmetics that one is using & 4.34 & 0.66 \\
\hline One must be able to accurately diagnose the customer's skin condition & 4.18 & 0.74 \\
\hline One must have the ability to handle unexpected situations during management & 4.26 & 0.60 \\
\hline One must be able to accurately determine customers' needs & 4.30 & 0.66 \\
\hline One must be able to recommend cosmetic products to improve customers' skin conditions & 4.31 & 0.69 \\
\hline Total & 4.22 & 0.57 \\
\hline
\end{tabular}

${ }^{*} p<0.05$. 
본 연구는 맞춤형화장품조제관리사와 피부미용사 두 직무 간의 상호 관련성과 현행 맞춤형화장품조제관리사국가자격시험제도의 효율성을 동시에 향상시킬 수 있는 개선 방안을 제언하고자 한다.

\section{Methods}

\section{1. 연구참여자 및 기간}

본 연구는 연구대상자를 현업 피부미용사로 설정하되 맞춤형화 장품조제관리사 자격증을 취득하였거나 취득 예정인 자로 제한하였 다. 2020년 2월 첫 자격시험을 앞둔 시점인 1월부터 한달 간 (1월 6 일부터 2월 3 일까지) 전국의 피부미용사 500 명을 대상으로 맞춤형 화장품조제관리사 자격시험에 대해 알고 있는지 응시 계획은 있는 지 등을 온라인으로 사전 조사하였고 이에 응시 계획이 있다고 답한 154 명을 1 차적으로 선정하였다. 그리고 이들을 대상으로 첫 자격시 험의 합격자 발표 이후 시점인 2020년 3월 15 일에 온라인 설문지를 배포하였다. 3월 15 일부터 3월 22일까지 설문조사를 받아서 총 140 건을 확보하였고, 누락이나 불성실 기재 등의 문제가 있는 9 건을 제 외한 나머지 131 건을 연구에 활용하였다.

\section{2. 측정 도구}

1) 설문지 구성

본 연구는 한국산업인력공단의 피부미용사 교육훈련과정의 교과 편성에 대한 만족도와 실무능력 및 전문성과의 영향관계를 분석하 기 위해서 NCS의 '미용사(피부)교육훈련과정'이 '전문성' 및 '실무능 력'에 미치는 영향 연구(Kim \& Lee, 2014)와 한국 이미용 국가기술 자격증에 대한 인식 연구(Kam \& Kim, 2019), 연령별 여성소비자 의 맞춤형화장품 사용실태 및 선호유형(Kong \& Kim, 2018)을 연구
한 선행 논문의 설문 구성을 바탕으로 본 연구의 목적에 맞게 수정 보완하였다.

\section{2) 자료 분석}

수집된 자료를 분석하기 위해 통계 패키지 프로그램 Statistical Package for Social Science (SPSS) v.18을 사용하였고, 통계처리 에 앞서 데이터 코딩(data coding) 및 데이터 클리닝(data cleaning) 과정을 진행하였다.

연구대상 피부미용사의 직업적 특성 중의 4 문항, 맞춤형화장품 에 대한 전반적 인식, 맞춤형화장품조제관리사와의 직무관련성 인 식 수준, 맞춤형화장품조제관리사 국가자격시험제도 및 교과편성에 대한 만족 수준은 기술통계를 이용하여 빈도, 백분율, 평균, 표준편 차로 제시하였다. 연구대상 피부미용사의 직업적 특성 중의 2 문항, 즉 직업적 특성에 따른 맞춤형화장품조제관리사 자격증을 취득했거 나 취득하려는 이유를 묻는 문항과 고객의 피부상태에 대해 맞춤형 화장품조제관리사보다 피부미용사가 더 잘 알고 있다면 그 이유가 무엇 때문이라고 생각하는지를 묻는 문항은 교차분석(Chi-Square test)을 통해 제시하였다. 연령, 학력, 실무경력 기간에 따른 맞춤형 화장품조제관리사 국가자격시험제도 및 교과편성 만족 수준을 구 분하기 위해 독립표본t검정(t-test), 일원배치 분산분석(one-way ANOVA)을 통하여 제시하였다.

개방형 문항은 연구대상자가 16 개 항목 중에 복수선택한 결과와 10 개 항목 가운데 복수선택한 결과는 선택 인원을 기준으로 순위를 각각 매기는 방식으로 제시하였다. 연구대상자의 개인적 의견은 수 집 정리 절차를 거쳐 서술하는 방식으로 제시하였다.

Table 2. Recognition level of job relatedness of beauticians and customized cosmetic preparation managers regarding the measure of skin care job performance set by the NCS

$(\mathbf{N}=\mathbf{1 3 1})$

\begin{tabular}{|c|c|c|}
\hline Questions & Mean & Standard deviation \\
\hline Cleansing & 3.73 & 0.98 \\
\hline Evaluating skin condition analysis & 4.29 & 0.78 \\
\hline Forming a skin care plan & 4.18 & 0.76 \\
\hline Categorizing cosmetics & 4.31 & 0.66 \\
\hline Using basic skin care products & 4.14 & 0.76 \\
\hline Using functional skin care products & 4.15 & 0.69 \\
\hline Using body care products & 3.69 & 0.85 \\
\hline Using color cosmetics & 3.55 & 1.04 \\
\hline Using aromatic cosmetics & 3.50 & 1.04 \\
\hline Managing hygiene within the skin care workshop & 4.09 & 0.86 \\
\hline Managing sanitation of skin care equipment & 4.02 & 0.87 \\
\hline Managing employee hygiene & 4.10 & 0.78 \\
\hline Counseling post-treatment & 4.18 & 0.84 \\
\hline Managing customer retention & 4.15 & 0.79 \\
\hline Total & 4.01 & 0.62 \\
\hline
\end{tabular}




\section{Results}

\section{1. 맞춤형화장품조제관리사 업무와의 직무관련성 인식 수준}

연구대상 피부미용사가 피부미용사와 맞춤형화장품조제관리사의 직무관련성에 대해 어떻게 인식하고 있는지 결과값을 정리하면 다 음과 같다.

1) 현장실무 전문성 측면의 직무관련성

현장실무의 전문성 측면에서 본 직무관련성 인식 수준을 평가결 과는 Table 1 과 같이 나타내었다. 그 결과, 8 문항은 평균 4.22점( \pm 0.57)의 결과값을 나타내었다. 세부 문항에서는 '자신이 다루는 화 장품을 충분히 이해해야 한다'는 인식이 4.34 점 $( \pm 0.66)$ 으로 가장 높았고, '피부미용에 관한 많은 지식이 있어야 한다'는 인식이 4.05 점 $( \pm 0.75)$ 으로 가장 낮았다.

자신이 다루는 화장품을 충분히 이해해야 한다는 인식 수준과 고 객의 니즈를 정확하게 판단할 줄 알아야 한다는 인식 수준이 높았 다. 이는 소비자들에게 객관적이고 신뢰할 수 있는 정보를 제공했을 때 긍정적 마케팅 효과를 기대할 수 있다(Son et al., 2019)는 연구 결과와 일치한다. 피부미용사와 맞춤형화장품조제관리사는 공통적 으로 충분한 화장품 이해도를 바탕으로 고객 니즈에 부응할 수 있어 야 하므로 상호 간의 직무관련성을 높게 인식한 결과라고 볼 수 있 다.

\section{2) NCS 능력단위요소 측면의 직무관련성}

$\mathrm{NCS}$ 는 산업현장의 요구에 적합한 인력을 즉각적이고 체계적으로 양성하는 것을 우선과제로 하고 있다(Kim \& Lee, 2014). NCS가 제 시한 피부미용직무 능력단위 요소 측면에서 본 직무관련성 인식 수
준 평가는 Table 2 와 같이 나타냈다. 총 평가 문항은 16 개이며, 이는 평균 4.01점 $( \pm 0.62)$ 의 결과값을 나타내었다. 세부 문항 가운데 '화 장품 분류하기' 요소가 4.31점(0.66)으로 직무관련성이 가장 높다고 인식했으며, '방향성 화장품 사용하기' 요소는 3.50점(1.04)으로 직 무관련성이 가장 낮게 나타났다. 화장품 분류하기 요소의 인식 수준 이 가장 높았고, 피부상태 분석평가하기 요소가 다음으로 높았다.

$\mathrm{NCS}$ 맞춤형화장품조제관리 직무능력 단위는 아직 마련되지 않았 으나 화장품 분류하기, 피부상태 분석평가하기 등의 피부미용 직무 능력단위는 피부미용사와 맞춤형화장품조제관리사의 공통적으로 요구되는 능력이고 따라서 직무관련성을 나타내는 지표가 됨을 알 수 있었다.

\section{3) 한국산업인력공단 교육훈련과정 측면의 직무관련성}

한국산업인력공단이 제시한 피부미용사 교육훈련과정 측면에서 본 직무관련성은 18 개의 문항으로 구성해 조사하였는데, 항목별 인 식 수준은 평균 3.73 점 $( \pm 0.68)$ 의 결과값을 나타내었다. 세부 문 항 가운데 '피부분석(상담 및 피부관리 계획)' 교육훈련이 4.13점( \pm 0.90)으로 직무관련성이 가장 높다고 인식했으며, '네일미용(손톱, 발톱, 폴리쉬 등)' 교육훈련은 3.17점 $( \pm 1.05)$ 으로 직무관련성을 가 장 낮다고 인식하였다. 피부분석이 가장 높았고 화장품학이 다음으 로 높았다. 즉 피부미용사와 맞춤형화장품조제관리사는 피부분석 능력과 화장품 지식을 구비해야 한다는 공통점이 있으므로 직무관 련성을 높게 인식한 것으로 해석된다. 화장품과 피부미용이 밀접한 관계가 있으므로 이를 다루는 각각의 전문가 또한 높은 직무관련성 이 있다고 인식한 결과라 하겠다. 이를 정리하면 Table 3 과 같다.

Table 3. Recognition level of job relatedness of beauticians and customized cosmetic preparation managers regarding the beautician education training process set by the Human Resources Development Services of Korea

\begin{tabular}{llc}
\hline Questions & Mean & Standard deviation \\
Beauty dermatology & 3.98 & 0.84 \\
Dermatology & 4.05 & 0.94 \\
Anatomy and physiology & 3.61 & 1.02 \\
Study of skin analysis equipment (types and use) & 3.61 & 1.01 \\
Cosmetology (introduction and production, types, and functions) & 4.11 & 3.86 \\
Study of public hygiene management (study of public health and disinfection and public & 3.91 & 0.90 \\
health-related laws) & 4.13 & 0.90 \\
Skin hygiene control (general hygiene control) & 3.74 & 0.92 \\
Skin analysis (counseling and skin care planning) & 3.54 & 0.95 \\
Skin cleansing (cleansing and deep-cleansing) & 3.85 & 0.99 \\
Skin management (manual technique) & 3.65 & 0.95 \\
Skin nutrition care (face pack and face mask) & 3.59 & 0.94 \\
Special skin care (various therapies, hair removal spa, etc.) & 3.83 & 0.98 \\
Beauty hygiene control 1 (management of the cleanliness of the make-up room and & 3.44 \\
equipment preparation) & 3.17 & 0.84 \\
Beauty hygiene control 2 (management of the cleanliness of the skin care shop and & 3.56 \\
equipment disinfection, material preparation) & 3.46 & 1.06 \\
Makeup (modification and supplementation of skin, eyes, lips, and cheeks) & 3.73 \\
Nail beauty (fingernail, toenail, polish, etc.) & & 1.05 \\
Scalp care (scalp and hair care) & & 0.96 \\
Management of skin care equipment & & 0.68 \\
\hline Total & & \\
\hline
\end{tabular}




\section{2. 맞춤형화장품조제관리사 국가자격시험제도에 대한 만족 수준}

본 연구의 연구대상 피부미용사의 맞춤형화장품조제관리사 국가 자격증 시험제도에 대한 만족 수준을 분석한 결과는 Table 4 와 같 이 나타내었다. 평균 3.11점 $( \pm 0.62)$ 이며, '맞춤형화장품조제관리사 자격증 취득 후 재교육이 필요하다'가 3.92점 $( \pm 0.99)$ 으로 가장 높 게 나타났으며, '맞춤형화장품조제관리사 자격증 취득을 위한 교육 체계가 잘 갖추어져 있다' 항목은 2.37 점 $( \pm 1.12)$ 으로 가장 낮게 나 타났다. 피부미용 업 및 피부미용사의 경쟁력 향상과 관련된 항목의 만족 수준이 대체로 높았다. '맞춤형화장품조제관리사 자격증은 피 부미용업계에서 활용도가 높다', '맞춤형화장품조제관리사자격증 취 득이 피부관리실 매출증대에 도움이 될 것이다', '맞춤형화장품조제 관리사 자격증 취득은 피부미용사 직무능력과 경쟁력을 향상시켜줄 것이다 항목을 긍정한 비율도 매우 높았다. 그러나 시험 운영방식에 대한 만족 수준은 대체로 낮게 나타나 대조를 이루었다. '맞춤형화장 품조제관리사 자격시험을 통해 응시자의 맞춤형화장품조제관리 능 력을 정확히 평가할 수 있다', '맞춤형화장품조제관리사 자격증 취득 을 위한 교육 체계가 잘 갖추어져 있다', '맞춤형화장품조제관리사는 현행대로 응시자격 제한이 없어야 한다' 항목을 부정한 비율이 높았 고, '맞춤형화장품조제관리사는 현행대로 검정방식이 실기 없이 이 론만으로 구성되어야 한다', '맞춤형화장품조제관리사 자격증을 취 득 후 곧 바로 현장 업무 수행이 가능하다' 항목을 부정한 비율은 그 가운데 가장 높게 나타났다.

\section{3. 맞춤형화장품조제관리사 국가자격시험 교과편성에 대한 만족} 수준

맞춤형화장품조제관리사 국가자격시험 교과편성에 대한 연구대 상 피부미용사의 만족 수준 분석한 결과는 Table 5 와 같이 나타냈 다. 분석결과 체계적 교과편성을 위해 NCS 능력요소 개발이 선행되 어야 함을 긍정한 비율이 3.89점 $( \pm 0.95)$ 으로 가장 높았고 다음으 로 고객상담 관련 교과의 보강 및 실습형 시험교과가 추가되어야 함 을 긍정한 비율이 높았다. 이러한 항목은 각계각층에서 현행 교과편 성의 문제점으로 이미 지적된 바 있는데, 피부미용사의 만족 수준을 분석한 결과에서도 동일한 문제의식이 나타난 것으로 해석된다. '방 향성 맞춤화장품 제조를 위해 향에 대한 실습교과는 별도로 필요하 지 않다고 생각하십니까?' 항목과 '자격시험 문항의 배점기준이 비공 개인 것에 대해 만족하십니까?' 항목을 부정한 인원이 131 명 가운데 78 명과 86명으로 각각 나타나 특히 이 두 항목의 만족 수준이 낮음 을 알 수 있었다. 화장품 사용제한 원료에 관한 내용이나 분량에 대 해서도 만족 수준이 비교적 낮게 나타났다.

\section{4. 맞춤형화장품조제관리사 국가자격시험제도 및 교과편성 개선 요구 사항}

1) 국가자격제도 개선 요구 사항 및 수준 비교

맞춤형화장품조제관리사 국가자격증 시험제도에 대한 연구대상 피부미용사의 만족 수준을 파악하기 위한 16 개의 설문문항 가운데

Table 4. Comparison of the satisfaction level of the national qualifying examination system for becoming a customized cosmetic preparation manager

( $\mathbf{N}=\mathbf{1 3 1})$

\begin{tabular}{llc}
\hline Questions & Mean & $\begin{array}{c}\text { Standard } \\
\text { deviation }\end{array}$ \\
$\begin{array}{l}\text { Qualifying examination for becoming a customized cosmetic preparation manager reflects the } \\
\text { nature of the industry }\end{array}$ & 3.14 \\
$\begin{array}{l}\text { Qualifying examination for becoming a customized cosmetic preparation manager reflects the } \\
\text { skin care work in the field }\end{array}$ & 2.98 \\
$\begin{array}{l}\text { Qualifying examination for becoming a customized cosmetic preparation manager clearly } \\
\text { distinguishes the scope of the work }\end{array}$ & 2.87 \\
$\begin{array}{l}\text { Qualifying examination for becoming a customized cosmetic preparation manager can be used } \\
\text { to accurately evaluate the examinee's customized cosmetic preparation management skills }\end{array}$ & 2.79 \\
$\begin{array}{l}\text { Education system for acquiring a certification in customized cosmetic preparation management } \\
\text { is well developed }\end{array}$ & 2.37 \\
$\begin{array}{l}\text { Acquiring a certification in customized cosmetic preparation requires a large amount of time and } \\
\text { expenses }\end{array}$ & 3.42 \\
$\begin{array}{l}\text { Becoming a customized cosmetic preparation manager requires one to have no constraints on } \\
\text { application eligibility }\end{array}$ & 2.84 \\
$\begin{array}{l}\text { A customized cosmetic preparation manager should be tested only on theories and not on } \\
\text { practical techniques }\end{array}$ & 2.47 \\
$\begin{array}{l}\text { The qualifying examination for becoming a customized cosmetic preparation manager should } \\
\text { maintain a certain difficulty level }\end{array}$ & 3.00 \\
$\begin{array}{l}\text { After acquiring a certification in customized cosmetic preparation management, re-education is } \\
\text { necessary }\end{array}$ & 3.92 \\
$\begin{array}{l}\text { A certification in customized cosmetic preparation management is required } \\
\text { Acquiring a certification in customized cosmetic preparation is highly useful in skin care industry } \\
\text { management and would help increase sales of skin care stores }\end{array}$ & 3.53 \\
$\begin{array}{l}\text { Acquiring a certification in customized cosmetic preparation management would enhance the } \\
\text { job performance and competitiveness of the beautician } \\
\text { When employing a beautician, whether one possesses a certification in customized cosmetic } \\
\text { preparation management would be a key factor } \\
\text { I would recommend other beauticians to obtain a certification in customized cosmetic } \\
\text { preparation management }\end{array}$ & 3.64 \\
\begin{tabular}{l} 
Total \\
\hline
\end{tabular} & 3.75 \\
\hline
\end{tabular}


개선이 필요한 항목을 복수 선택하게 하였다. 그 결과 Table 6과 같 이 나타냈다. '맞춤형화장품조제관리사 국가자격증 검정 방식이 실 기 없이 이론만으로 구성되어야 한다'를 선택한 인원이 131 명 가운 데 46 명으로 가장 많아 이론 $100 \%$ 의 시험제도 개선 요구가 가장 높 음을 알 수 있었다. 그 다음으로 높게 집계된 것은 '맞춤형화장품조 제관리사 자격증 취득 후 곧바로 현장 업무 수행하는 것이 가능하 다' 항목으로 이를 선택한 인원은 43 명이었다. 자격증 취득과 현장 업무를 직접적 연계하도록 하는 개선 요구 또한 높았다고 볼 수 있 다. 그 다음으로 '맞춤형화장품조제관리사 자격증 취득을 위한 교육 체계가 잘 갖추어져 있다' 항목이 33명, '맞춤형화장품조제관리사 자 격증 시험은 현행대로 시험난이도를 유지해야 한다' 항목이 24 명, 맞춤형화장품조제관리사 자격증 취득 후 재교육이 필요하다' 항목도 24 명, '맞춤형화장품조제관리사 자격시험을 통해 응시자의 맞춤형 화장품조제관리 능력을 정확히 평가할 수 있다' 항목이 23 명, '맞춤 형화장품조제관리사 자격시험은 현행대로 응시자격 제한이 없어야 한다' 항목이 23 명, '맞춤형화장품조제관리사 자격시험제도가 피부 미용 현장 실무를 반영하고 있다' 항목이 21 명, '맞춤형화장품조제관 리사 자격증을 취득하는데 드는 시간과 비용이 많은 편이다' 항목이 19 명, '맞춤형화장품조제관리사 자격시험제도는 피부미용업계의 특 성을 반영하고 있다' 항목이 17 명, '맞춤형화장품조제관리사 자격시 험제도는 직무영역을 명확히 구분하고 있다' 항목도 17 명, '피부미용 사 채용 시 맞춤형화장품조제관리사 자격증 소지여부가 관건이 될 것이다' 항목은 14 명, '맞춤형화장품조제관리사 자격증은 피부미용 업계에서 활용도가 높다' 항목은 12 명, '맞춤형화장품조제관리사 자 격증 취득이 피부관리실 매출증대에 도움이 될 것이다' 항목은 11 명 이며 '맞춤형화장품조제관리사 자격증 취득은 피부미용사의 직무능 력과 경쟁력을 향상시켜 줄 것이다' 항목은 10 명, '다른 피부미용사 에게 맞춤형화장품조제관리사 자격증 취득을 권유할 것이다' 항목이
8명으로 순차적 결과를 나타내었다.

맞춤형화장품조제관리사 국가자격시험의 개선 필요성에 대한 의 견을 정리하면 다음과 같다. 자격증 취득과 현장 업무가 바로 연계 되지 못한다는 점에 대한 개선 요구 또한 높았다. 자격증 취득을 위 한 교육체계를 갖추지 못한 점을 지적한 인원도 많았고, 응시자격 에 제한을 두지 않는 점을 개선해야한다고 보는 이도 많았다. 반면 여러 항목 가운데 피부미용업과의 연계가능성이나 피부미용사의 직 무경쟁력 향상과 관련해 개선을 요구한 인원을 상대적으로 적었다. 즉, 피부미용업 내지 피부미용사의 경쟁력 향상과 관련된 항목들에 대한 만족 수준이 높게 나왔던 만큼 자격 제도 도입 자체에 대해서 는 대체로 긍정적인 반응을 보인다고 하겠다. 다만 효율적 시험 운 영과 관련된 체계와 기준이 미흡한 것으로 간주하는 경향이 있었고 따라서 개선 요구 또한 바로 이 부분에 집중되고 있었다. 검정방식 개선 요구를 구체적으로 서술한 답변들을 살펴보면, 실무능력이 중 요한 자격증임에도 불구하고 이론 $100 \%$ 만으로 이루어지는 것은 불 합리하며 예를 들어 이론 $50 \%$, 실기 $50 \%$ 등으로 시험 구성 비율이 조 절되어 한다는 의견이 많았다. 또한 실무 능력을 보장하는 자격증이 라야 소비자에게 신뢰를 줄 수 있을 것이라는 의견이 제시되기도 하 였다. 자격증 취득과 현장 업무가 바로 연계되지 못한다는 점에 지 적하며 사전실습교육을 실시한 후 실기검정을 통해 자격을 부여해 야 한다는 개선 방안을 내놓기도 하였다. 또한 실기검정과 응시자격 제한이 없다는 점을 함께 지적하며 현행대로 자격 시험 제도가 운영 된다면 현업 화장품실무 종사자를 제외한 나머지는 직무 능력을 제 대로 갖추지 못한 채 방치되거나 별도의 비용을 들여 사교육을 받아 야 할 것이라고 하였다. 따라서 조속히 표준화된 교육체계를 마련하 여 공인된 교육기관을 통해 실무교육을 받을 수 있도록 해야 한다고 보았다. 또한 온라인 교육시스템을 확충하여 교육기회를 확대해 나 가야 한다고 하였다

Table 5. Comparison of the satisfaction level of subject organization of the national qualifying examination system for becoming a customized cosmetic preparation manager

( $N=131)$

\begin{tabular}{|c|c|c|}
\hline Questions & Mean & Standard deviation \\
\hline $\begin{array}{l}\text { Do you think that including the personal information protection act in subjects related to } \\
\text { understanding the cosmetics act is appropriate? }\end{array}$ & 3.26 & 0.94 \\
\hline $\begin{array}{l}\text { Do you think that the standards for a facility for a cosmetic preparation workshop on safety } \\
\text { control of cosmetics in the market are appropriate? }\end{array}$ & 3.07 & 0.99 \\
\hline $\begin{array}{l}\text { Do you think that the length or content of the topic on base materials of cosmetics on } \\
\text { preparation and quality management of cosmetics is appropriate? }\end{array}$ & 3.17 & 1.10 \\
\hline $\begin{array}{l}\text { Do you think that the length or content of the explanation of base materials with } \\
\text { restrictions on usage on preparation and quality management of cosmetics is appropriate? }\end{array}$ & 3.16 & 1.07 \\
\hline $\begin{array}{l}\text { Do you think that it is necessary to have a separate subject on practical techniques related } \\
\text { to skin analysis equipment usage on understanding customized cosmetics? }\end{array}$ & 3.53 & 1.05 \\
\hline $\begin{array}{l}\text { Do you think that it is necessary to have a separate subject on practical techniques related } \\
\text { to fragrance for customized aromatic cosmetic preparation? }\end{array}$ & 2.47 & 1.11 \\
\hline $\begin{array}{l}\text { Do you think that the content or length of explanation on customer counseling on } \\
\text { understanding customized cosmetics is appropriate? }\end{array}$ & 3.65 & 1.04 \\
\hline Do you think that two hours to solve 100 questions is appropriate? & 2.92 & 1.02 \\
\hline $\begin{array}{l}\text { Do you think that the standards of scoring questions on the qualifying examination are } \\
\text { appropriate? }\end{array}$ & 2.21 & 1.22 \\
\hline $\begin{array}{l}\text { Do you think that the development of NCS elements of competences should precede } \\
\text { subject organization? }\end{array}$ & 3.89 & 0.95 \\
\hline Total & 3.13 & 0.58 \\
\hline
\end{tabular}




\section{2) 국가자격시험 교과편성 개선 요구 사항 및 수준 비교}

맞춤형화장품조제관리사 국가자격증 시험제도에 대한 연구대상 피부미용사의 만족 수준을 파악하기 위한 10 개의 설문 문항 가운데 개선이 필요한 항목을 복수 선택하게 하였다. 그 결과 '자격시험 문 항의 배점 기준이 비공개인 것이 합당하다고 생각하십니까?' 항목을 개선이 필요하다고 선택한 대상자가 44 명으로 가장 많았다. 그리고 '방향성맞춤형화장품조제를 위해 향에 대한 실습 교과는 별도로 필 요하지 않다고 생각하십니까' 항목을 선택한 인원이 43명으로 나타 나 개선 요구가 집중적임을 알 수 있었다. 그 다음으로 '100문항에 2 시간 주어지는 시험시간은 적당하다고 생각하십니까?' 항목은 29 명, '맞춤형화장품의 이해 교과에서 피부분석 기기사용에 관한 실습교과 가 별도로 필요하다고 생각하십니까' 항목은 24 명, '교과편성에 있 어 NCS 능력요소 개발이 선행되어야 한다고 생각하십니까? 항목은 24명, '화장품 제조 및 품질관리 교과에서 화장품원료에 관한 내용 이나 분량은 적당하다고 생각하십니까?' 항목은 23 명, '유통화장품 안전관리 교과에서 제시하는 조제 작업장 시설기준은 적당하다고 생각하십니까?'항목은 21 명, '화장품 제조 및 품질 관리 교과에서 사 용제한 원료에 관한 내용이나 분량은 적당하다고 생각하십니까?' 항 목은 21 명, '맞춤형화장품의 이해 교과에서 고객 상담에 관한 내용 이나 분량은 적당하다고 생각하십니까?' 항목은 19 명, '화장품법의 이해 교과에서 개인정보보호법이 포함된 것은 적당하다고 생각하십
니까?' 10 명이 선택해 개선 요구 수준에 차이가 있었다. 이상의 내용 을 정리하면 Table7과 같다.

맞춤형화장품조제관리사 국가자격시험 교과편성 만족 수준을 파 악하는 10 개의 항목 가운데 개선이 요구되는 항목을 복수선택 하게 한 결과, 시험 문항의 배점기준이 비공개라는 점을 꼽은 인원이 가 장 많았다. 향에 대한 실습없이 이론만으로 방향성맞춤형화장품조 제를 학습한다는 것은 불합리하므로 이에 대한 개선이 필요하다고 보는 인원도 많았다. 또 다수가 시험시간을 개선할 것을 요구하였 다. NCS 능력단위 개발이 선행되어야 하고 피부분석기기 사용과 관 련된 실습 교과가 추가되어야 하며, 화장품 관련 교과의 내용 및 분 량도 개선의 필요가 있다고 지적한 이가 많았다. 한편 100 문항에 시 험시간 2 시간으로 진행되는 현행 검정방식을 개선할 필요가 있다고 본 이들도 많았다. 유통화장품 안전관리 교과에서 제시한 조제 작업 장 시설기준을 개선점으로 꼽은 인원도 적지 않았다. 이러한 개선 요구를 구체적으로 서술한 답변들을 살펴보면 우선 배점 기준을 공 개해야 응시자가 공정성 여부를 확인할 수 있고 특히 단답형 문항의 반드시 자세한 채점 기준이 제시되어야 한다는 의견이 있었다. 배 점 기준 및 시험 문항을 공개하면 응시자는 검정 준비를 더욱 정확 히 할 있다고도 하였다. 방향성 제품을 조제하기 위해서는 향에 대 한 실습이 있어야 하고 피부분석을 위해서는 기기사용에 대한 실습 이 반드시 수반되어야 하며 이에 관한 실습 교과 편성이 시급하다고

Table 6. Comparison of the levels of requirements related to the national qualifying examination system on becoming a customized cosmetic preparation manager (can choose multiple options)

\begin{tabular}{|c|c|c|}
\hline Ranking & Questions & $\begin{array}{c}\text { Number of } \\
\text { subjects } \\
\text { (with multiple } \\
\text { options) }\end{array}$ \\
\hline 1 & $\begin{array}{l}\text { The examination on becoming a customized cosmetic preparation manager should contain only theory with no } \\
\text { practical techniques such as that at present }\end{array}$ & 46 \\
\hline 2 & $\begin{array}{l}\text { It is possible to start work in the field immediately after acquiring a certification on customized cosmetic } \\
\text { preparation management }\end{array}$ & 43 \\
\hline 3 & $\begin{array}{l}\text { The education system for acquiring a certification in customized cosmetic preparation management is well } \\
\text { developed }\end{array}$ & 33 \\
\hline 4 & $\begin{array}{l}\text { The difficulty of the qualifying examination for becoming a customized cosmetic preparation manager should be } \\
\text { maintained such as that at present }\end{array}$ & 24 \\
\hline 5 & Re-education after acquiring a certification in customized cosmetic preparation management is necessary & 24 \\
\hline 6 & $\begin{array}{l}\text { There should be no restrictions on examination eligibility for becoming a customized cosmetic preparation } \\
\text { manager such as that at present }\end{array}$ & 23 \\
\hline 7 & $\begin{array}{l}\text { One can accurately evaluate the customized cosmetic preparation management skills of the examinee using the } \\
\text { qualifying examination for becoming a customized cosmetic preparation manager. }\end{array}$ & 23 \\
\hline 8 & $\begin{array}{l}\text { The qualifying examination system for becoming a customized cosmetic preparation manager reflects the skin } \\
\text { care work in the field }\end{array}$ & 21 \\
\hline 9 & $\begin{array}{l}\text { Acquiring a certification in customized cosmetic preparation management requires substantial time and } \\
\text { expenses }\end{array}$ & 19 \\
\hline 10 & $\begin{array}{l}\text { The work scope is clearly distinguished in the qualifying examination system for becoming a customized } \\
\text { cosmetic preparation manager }\end{array}$ & 17 \\
\hline 11 & $\begin{array}{l}\text { The qualifying examination system for becoming a customized cosmetic preparation manager reflects the nature } \\
\text { of the skin care industry }\end{array}$ & 17 \\
\hline 12 & $\begin{array}{l}\text { When hiring a beautician, whether one possesses a certification in customized cosmetic preparation } \\
\text { management would be a key factor }\end{array}$ & 14 \\
\hline 13 & A certification in customized cosmetic preparation management is very useful in the skin care industry & 12 \\
\hline 14 & $\begin{array}{l}\text { Acquiring a certification in customized cosmetic preparation management would help increase the sales of the } \\
\text { skin care store }\end{array}$ & 11 \\
\hline 15 & $\begin{array}{l}\text { Acquiring a certification in customized cosmetic preparation management would enhance the work performance } \\
\text { and competitiveness of the beautician }\end{array}$ & 10 \\
\hline 16 & I will recommend other beauticians to obtain a certification in customized cosmetic preparation management & 8 \\
\hline
\end{tabular}


하였다. 화장품의 원료와 성분에 대한 전문성을 갖추기 위해서는 이 론 학습이 중요한 것은 맞지만 그 내용이 광범위하고 복잡하게 구성 되어 있는 점, 화학적 지식을 쌓도록 교과가 편성되어 있어 화공학 을 전공한 대기업 화장품 직원을 위한 자격증처럼 보이는 점은 개선 이 필요하다고 하였다. 한편 이론 교과를 학습해 100 문항 시험을 치 르다 보니 학습내용이 방대한 것에 비해 시험문제는 지엽적인 내용 에서 출제되는 경향이 있어 개선이 필요하다는 의견이 제시되기도 하였다. 현재의 작업장 위생시설기준은 대규모 화장품 제조 업체에 나 적용가능한 것이므로 영세자영업자들이 갖출 수 있는 보편적 영 업공간 규모 고려해 시설기준을 완화할 필요가 있다는 의견이 있었 다.

\section{Discussion}

본 연구에서는 현행 맞춤형화장품조제관리사 국가자격시험제도 를 연구함에 있어 맞춤형화장품조제관리사와 피부미용사의 직무관 련성 분석에 중점을 두었다. 화장품과 피부미용의 밀접한 상관성은 화장품과 관련된 업무 부분이 피부미용사의 직무영역에 포함되어 있다고 밝힌 선행 논문(Jeong, 2012)과 일치하듯이 맞춤형화장품조 제관리사와 피부미용사에게 요구되는 직무능력에는 공통점이 나타 날 수 있다. 맞품형 화장품 및 피부미용 시장 특성과 변화 추세를 파 악해 본 결과 최근 개인 맞춤형 소비 트렌드가 형성됨에 따라 맞춤 형화장품 시장이 활황세임을 알 수 있었고, 이는 건강한 아름다움을 추구하는 현대인의 욕구가 강해짐에 따라 피부미용 관련 소비가 늘 어가고 있다(Cha \& Ahn, 2011)는 연구 결과와도 일치하며,화장품 구매자의 소비추세가 점점 가치지향적으로 변해가고 있다(Kang \& Hwang, 2007)는 연구 결과와도 일치한다. 맞춤형화장품이 피부 분 석을 기반으로 개인 피부 상태에 맞게 만들어지는 것이므로 심층 피
부미용 서비스의 일환으로 조제, 판매가 이루어진다면 피부미용 및 맞춤형화장품 전반에 대한 소비자 만족이 향상될 것으로 예상되었 다. 이는 맞춤형화장품 사업의 특성상 제품을 매장에서 직접 조제 하기 때문에 얼굴분석기술을 활용한 뷰티테크 서비스가 강화되어야 한다(Kim, 2017)는 선행논문의 인식연구와 같은 결과를 보였다. 이 러한 기대감 속에 피부미용 업계에서 맞춤형화장품 및 맞춤형화장 품조제관리사 자격증에 대한 호응이 높고 맞춤형화장품조제관리 능 력은 피부미용사의 경쟁력을 강화시키는 요인이 됨을 확인할 수 있 었다. 다만 제도화 시행 초기여서 여러 기준이 모호하고 직무능력표 준 등과 같은 교육체계 또한 갖추어지지 않았다는 점에서 향후 부단 한 개선 노력이 필요함을 알 수 있었다. 검정 방식마저 실기없는 필 기이기 때문에 과연 시험을 통해 직무능력을 검증할 수 있을 것인 지, 교과내용에 화장품 및 미용 업계의 특성과 그 실무 현장의 특성 이 반영되어 있는지, 나아가 제도 운영 취지에 맞는 현실적 가치를 창출할 수 있을 것인지, 등의 문제점을 시사하였다.

이러한 시사점을 거울삼아 현장실무 전문성 측면과 국가직무능력 표준 측면, 국가자격시험 교과편성 측면에서 맞춤형화장품조제관리 사와 피부미용사의 직무관련성을 각각 고찰하였고, 이와 같은 분석 결과를 토대로 하여 맞춤형화장품조제관리사 국가자격시험제도 및 교과편성에 대한 연구대상자의 개선 요구 사항을 다음과 같이 정리 하고자 한다.

첫째, 실무능력 평가가 정확하게 이루어져야 하는 자격증이므로 필 기검정으로만 진행하는 현행 방식을 개선하여 실기검정을 추가 도 입하여야 한다.

둘째, 산업현장이 요구하는 직무 능력을 보장하는 자격증이 되어야 하므로, NCS 기반이 없는 현행 교과편성 방식을 개선하여 맞춤형 화장품조제관리 직무의 능력단위를 먼저 개발하고 그에 따라 교과 편성이 이루어지도록 해야 한다.

셋째, 피부분석 기기사용이나 화장품 조제 등을 이론 위주로 학습

Table 7. Comparison of the levels of requirements for improving the subject organization of the national qualifying examination for becoming a customized cosmetic preparation manger

\begin{tabular}{|c|c|c|}
\hline Ranking & Questions & $\begin{array}{c}\text { Number of } \\
\text { subjects } \\
\text { (with multiple } \\
\text { options) }\end{array}$ \\
\hline 1 & $\begin{array}{l}\text { Do you think that it is appropriate to not disclose the standards for scoring the questions on the qualifying } \\
\text { examination? }\end{array}$ & 46 \\
\hline 2 & $\begin{array}{l}\text { Do you think that it is unnecessary to have a separate subject on practical techniques related to fragrances for } \\
\text { customized aromatic cosmetic preparation management? }\end{array}$ & 43 \\
\hline 3 & Do you think that it is appropriate to give two hours to solve 100 questions? & 29 \\
\hline 4 & $\begin{array}{l}\text { Do you think that it is necessary to have a separate subject related to skin analysis equipment usage in the } \\
\text { subject on understanding customized cosmetics? }\end{array}$ & 24 \\
\hline 5 & Do you think that the development of the NCS elements of competences should precede subject organization? & 24 \\
\hline 6 & $\begin{array}{l}\text { Do you think that the content or length of the explanation on the base materials of cosmetics on preparation } \\
\text { and quality control of cosmetics is appropriate? }\end{array}$ & 23 \\
\hline 7 & $\begin{array}{l}\text { Do you think that the content or length of the explanation on base materials with restrictions on usage on } \\
\text { preparation and quality control of cosmetics is appropriate? }\end{array}$ & 21 \\
\hline 8 & $\begin{array}{l}\text { Do you think that the content or length of the explanation on customer service on understanding customized } \\
\text { cosmetics is appropriate? }\end{array}$ & 19 \\
\hline 9 & $\begin{array}{l}\text { Do you think that it is appropriate to include the personal information protection act on understanding the } \\
\text { cosmetics act? }\end{array}$ & 10 \\
\hline
\end{tabular}


하게 되면 이에 대한 실무능력을 갖추기 어려우므로, 내용이나 분 량을 보강하거나 이론형 교과로만 구성된 현행 방식을 개선하여 실 습형 교과를 추가 신설하여야 한다.

넷째, 현재 자격증 취득을 위한 교육체계가 미비하므로 이를 확충 하여 자격증 취득 후 곧 바로 실무 수행이 가능하도록 해야 한다.

다섯째, 현재의 자격증은 취득 후 재교육이 요구되므로 공인된 재 교육기관을 설치하거나, 재교육이 필요 없을 만큼의 기초 역량을 가진 자로 응시자격에 제한을 두어야 한다.

여섯째, 선다형 문항 및 단답형 문항의 배점 기준을 비공개 하는 불 공정하므로 이를 개선해야 한다.

맞춤형화장품산업과 자격증관련 제도의 상호 균형발전이 미흡한 현시점에서 자격증 취득자의 산업참여가 쉽지 않다는 현실을 감안 하여, 보다 실질적인 능력을 갖출 수 있는 자격증으로 자리메김 해 야 하는 것이 필요하다.

본 연구는 피부미용인들의 화장품과 관련한 직무관련성과 높은 관심을 반영하여 개선의 방향성을 제안하는 취지로 학문적인 목적 으로 진행되었으며, 피부미용사만을 연구대상자로 선정하였기 때문 에, 수험자 전체의 의견을 취합하지 못하였고, 일반화 하기엔 한계 가 따른다. 이후 실제 화장품관련 전공자와 전문가 입장에서 효율성 을 확인하는 연구가 필요하고, 뷰티와 미용관련 다양한 업종 종사자 들의 맞춤형화장품조제관리사자격증에 대한 인식 및 활용성에 대한 추가 연구 또한 진행되어야 할 것으로 보인다.

\section{Conclusion}

본 연구의 목적은 맞춤형화장품조제관리사와 피부미용사 두 직무 간의 상호 관련성과 현행 맞춤형화장품조제관리사국가자격시험제 도의 효율성을 동시에 향상시킬 수 있는 개선 방안을 제언하는 것이 다.

맞춤형화장품조제관리사 자격증을 취득하였거나 취득예정인 피 부미용사 131명을 대상으로 설문조사를 실시하고 SPSS v.18 통계 패키지를 통해 분석하였으며, 결과를 종합하여 피부미용사의 자격 증 취득 의도와 맞춤형화장품조제관리사 국가자격시험제도 도입 취 지에 동시에 부합되는 개선 방안을 아래와 같이 제언하고자 한다. 첫째, 피부미용사와 맞춤형화장품조제관리사의 전문지식을 연계하 는 방법이 있다.

피부미용사와 맞춤형화장품조제관리사, 두 자격증의 필기시험 교 과내용에서 상호 밀접한 관련성을 나타내는 항목이 존재하며, 화장 품을 피부에 적용시키는 것이 주요 업무영역인 공통점이 있다. 맞품 형화장품조제가 주로 고객의 피부를 기준으로 해서 이루어지는 행 위라는 것을 고려하면 맞춤형화장품조제관리사 시험교과편성 부분 에 포함된 피부에 대한 전문지식 부분의 내용 분량은 오히려 부족하 다. 피부미용사 자격검정 내용에서 다루는 교과목에는 오히려 피부
학을 시험교과로 따로 두고 있어서 고객의 피부의 상태를 분석한다 는 가장 중요한 활동이 이루어지기 위한 기본 교과목으로 자리했다. 맞춤형화장품조제관리사 본연의 직무와 거리가 있는 교과 내용을 축소하고, 상담 및 피부관리 계획 수립과 직결된 피부분석 관련 교 과를 추가하거나 그 내용을 확대할 필요가 있을 것으로 사료된다.

둘째, 맞춤형화장품 조제 실무와 피부 관리 실무 연계하는 방법이 있다.

피부미용은 직무능력표준(NCS)이 개발되어 있어서 좀더 명확한 이론적, 실무적 표준범위가 정해져 있다. 특히 '피부미용 피부분석', '피부미용 고객상담', '피부미용 고객마무리관리' 능력단위와 '피부미 용 화장품사용하기' 능력단위는 맞춤형화장품조제관리사와 직무관 련성이 높았다. 산업현장의 직무를 개발하고, 산업현장의 요구를 반 영하여 직무교육체계를 설계하려는 것이 직무능력표준의 기본 취지 이므로 직무능력표준에 나타난 피부미용사와

맞춤형화장품조제관리사의 직무관련성을 점검하는 방법도 맞춤 형화장품조제관리사의 현장실무능력을 정의하는 단초가 될 수 있을 것으로 사료된다.

셋째, 고객 상담 실무를 연계하는 방법이 있다.

맞춤형화장품은 고객의 니즈를 파악하여 적절한 제품을 추천하고 상세한 설명을 첨부하기 위해서는 전문적인 상담 능력이 요구된다. 맞춤형화장품조제관리사 자격시험에 고객 상담기술과 관련된 교과 를 편성하지 않은 것에 부정적 반응을 보인 응답자가 다수였고 이 에 대한 시급한 개선을 요구한 인원 또한 많았다. 화장품은 제품 사 용기간이 비교적 긴 편이므로 장기간에 걸쳐 수시 상담을 의뢰 받을 수 있으며, 따라서 사용방법 및 홈케어 조언 등의 상담 능력도 반드 시 필요하다는 점을 감안하면 교과 학습을 통해 피부미용 경력자가 아니더라도 상담을 준비하고 맞춤형 상담을 계획할 수 있도록 상담 기술을 익힐 수 있는 교과가 필요하다고 사료된다.

넷째, 맞춤형화장품 조제판매업과 피부미용업의 위생관리 기준을 연계하는 방법이 있다.

맞춤형화장품은 화장품법의 적용을 받고 있으며, 맞춤형화장품 조제 작업장 및 작업자의 위생관리 기준, 설비 및 기구관리 위생 기 준을 학습하도록 설계되어 있다. 피부미용사의 경우 미용사법과 별 개로 공중위생관리법의 적용을 받게 되고 따라서 작업장 및 작업자 의 위생관리 관리 감독을 받게 된다. 더욱이 맞춤형화장품 조제과정 은 위생관리가 매우 중요하다고 할 수 있기 때문에 맞춤형화장품판 매업 업체 한곳 한곳의 위생 규정 준수 여부를 관리 감독할 수 있는 조직 체계가 갖추어져야 할 것으로 사료된다.

이와 같은 체계 구축 노력은 맞춤형화장품조제관리사에 대한 사 회적 신뢰를 형성하여 자격증의 효용적 가치를 제고할 뿐 아니라 맞 춤형화장품 조제 판매업이 우리 사회에 건전하게 정착되는 기반으 로 작동할 것이라 사료된다

피부미용사는 합법적인 자격증을 지닌 업종이지만 끊임없이 직무 의 불안함으로 의료법과 맹인안마사법의 제약을 받고 있는 부분이 
존재하며, 반면에 화장품과 관련된 부분은 합법적 직무법위에 포함 되기 때문에 합리적으로 영역을 좀 더 확대시켜 줄 수 있는 디딤대 역할을 해주는 자격증으로서, 피부미용사에게 맞춤형화장품조제관 리사자격증취득은 타 직종보다 높은 관심과 기대를 갖게 된다. 이런 상황적 인식을 함께 고려 했을 때 피부미용사와 맞춤형화장품조제 관리사의 직무관련성 연구는 필요한 시점이라 할 수 있고 자격증 실 효성측면의 다양한 발전적 연구의 단초가 될 것으로 사료된다.

This work is part of the Ji-yu Hong's M.Sc. thesis at the Konkuk University, Seoul, Korea.

\section{Author's contribution}

JYH designed, performed experiments, analyzed data, and wrote the manuscript. YSK supervised the project. All figures are created by the author and the co-authors. All authors read and approved the final manuscript.

\section{Author details}

Ji-yu Hong (Graduate student), Department of Cosmetics Engineering, Konkuk University, 120 Neungdong-ro Gwangjin-gu, Seoul 05029, Korea; Young-Sam Kim (Professor), Department of Image Industry, Graduate School of Engineering, Konkuk University, 120 Neungdong-ro Gwangjin-gu, Seoul 05029, Korea.

\section{References}

Ansari A, Mela CF. E-Customization. Journal of Marketing Research, 40: 131-145, 2003.

Cha EJ, Ahn HS. Comparison of beautician national licensing system in Germany, United Kingdom, and South Korea. Korean Journal of Aesthetics and Cosmetics Society, 9: 141-151, 2011.

Choi KI. Research synthesis of skin trouble analysis according to age and customized cosmetics. The Journal of the Korean Society of Make-up Design, 12: 15-29, 2016.

Jeong $\mathrm{SH}$. A comparative study and improvement devices on the national and international beauty therapy qualification. Journal of Investigative Cosmetology, 8: 6773, 2012.

Pine BJ, Peppers D, Rogers M. Do you want to keep your customers forever? Harvard Business Review, 73: 103104, 1995.
Kam SJ, Kim JW. A study on the awareness of beauty-related national technical qualifications in Korea. Asia-pacific Journal of Multimedia Services Convergent with Art, Humanities, and Sociology, 9: 1-14. 2019.

Kang YH, Hwang JS. Transaction: The effect of shopping orientations of male and female consumer on the attitude toward sales clerk's service and shopping environments. Journal of the Korean Society of Clothing and Textiles, 31: 540-550, 2007.

Kim GM. A study on the change of the fourth industrial revolution and global beauty market. Journal of Cultural Product \& Design, 50: 221-231, 2017.

Kim HR, Lee IH. An effect of academic achievement for achievement for 'beautician (skin) education and training course' suggested by 'NCS' on profession and practice suitability. Journal of Korea Academica-Industrial Cooperation Society, 15: 3512-3523, 2014.

Kim JA, Oh YK. Purchase behavior and satisfaction of onlineonly brand cosmetics. Asian Journal of Beauty and Cosmetology, 16: 32-41, 2018.

Kim MJ. Affecting factors for job stress and client service of estheticians in the medical beauty industry. Asian Journal of Beauty and Cosmetology, 17: 157-168, 2019.

Kim MS. The theory and practice of esthetics. Hyunmoon Publishing, Seoul, pp137-146, 2003.

Kong SM, Kim MS. Usage of customized cosmetics and preferred customized cosmetic types by age in female consumers. Journal of Investigative Cosmetology, 14: 331-342. 2018.

Kwon YR, Kim MJ. A study on the consumer preference for promoting cosmetics sales in the independent skin beauty shop. Journal of Beauty Industry, 1: 65-79, 2010.

Lee JH, Yoon CS. A study of improvements on skin (beauty) national qualification certificates system and its problems. Journal of Beauty Industry, 4: 5-28, 2010.

Lee JR, Hong HS. Assessment on the adult women's facial skin condition after healthcare. Journal of Korean Biological Nursing Science, 2: 20-37, 2002.

Seo JH. A study on design strategy which follows in consumer value standard change. Industrial Design, 6: 39-50, 2012.

Shim YJ, Choi JS. A study on the development direction of the beauty industry according to the 4th industrial revolution. Journal of the Korean Society of Nail-art and 
Cosmetology, 5: 29-35, 2017.

Simonson I. Determinants of customer's response to customized offers: conceptual framework and research propositions. Journal of Marketing, 69: 32-45, 2005.

Son HJ, You SH, Park CH. Relationship between consumers' exploring cosmetics information behavior and satisfaction and recommendation intention. Asian Journal of Beauty and Cosmetology, 17: 499-509, 2019.

Zeithmal VA. Consumer perceptions of price, quality, and value: a means-end model and synthesis of evidence. Journal of Marketing, 52: 2-22, 1988. 


\section{국문초록}

\section{맞춤형화장품조제관리사 국가자격시험제도 개선방향성에 대한 연구}

홍지유, 김영삼 ${ }^{2 *}$

${ }^{1}$ 건국대학교 화장품공학과, 서울, 한국

${ }^{2}$ 건국대학교 산업대학원 이미지산업학과, 서울, 한국

목적: 본 연구는 맞춤형화장품조제관리사와 피부미용사 두 직무 간의 상호 관련성과 현행 맞춤형화장품조제관리사국가자격시험제 도의 효율성을 동시에 향상시킬 수 있는 개선 방안을 제언하고자 한다. 방법: 맞춤형화장품조제관리사 자격증을 취득하였거나 취 득예정인 피부미용사 131명을 대상으로 설문조사를 실시하고 SPSS(Statistcal Packagefor Social Science) v. 18 통계 패키지를 통 해 분석하였다. 결과: 피부미용사는 맞춤형화장품조제관리사 국가자격시험 제도 도입 자체에는 대체로 만족하였으나 실기검정이 없고, 응시자격 제한도 없으며 교육체계조차 갖추어지지 않은 상태에서 실무 능력 함양 및 평가가 제대로 이루어질 수 있을 것인지, 시험 운영 방식에 대체로 만족하지 못한다. 넷째, 교과편성에 적용된 맞춤형화장품조제관리사의 업무 범위나 직무능력이 무엇인지 명확한 기준을 알 수 없고 현장 실무에 꼭 필요한 교과가 없다는 점에서 현재의 교과편성에 대체로 만족하지 못한다. 결론: 현재의 맞춤형화장품조제관리사자격시험 교과 및 검정방식에 개선이 요구되며, 이에 앞서 맞춤형화장품조제관리의 직무능력표준이 개발 되어야 한다. 이와 같은 체계 구축 노력은 맞춤형화장품조제관리사에 대한 사회적 신뢰를 형성하여 자격증의 효용적 가치를 제고할 뿐 아니라 맞춤형화장품 조제 판매업이 우리 사회에 건전하게 정착되는 기반마련에 도움이 될 것이다.

핵심어: 맞춤형화장품조제관리사, 피부미용사, 직무관련성, 국가자격시험제도, 제도 개선

\section{참고문헌}

감승자, 김정원. 한국 이미용 국가기술자격증에 대한 인식 연구: 자격증 소지자와 준비생을 중심으로. 예술인문사회융합멀 티미디어논문지, 9:1-14, 2019.

강영화, 황진숙. 성인남녀의 의복쇼핑성향에 따른 판매원서비스와 매장환경에 대한 태도 연구. 한국의류학회지, $31: 450-$ $550,2007$.

공선미, 김민신. 연령별 여성소비자의 맞춤형화장품 사용실태 및 선호유형. 대한미용학회지, 14: 331-342, 2018. 권영랑, 김민정. 自營 피부미용실 화장품 판매촉진을 위한 소비자 선호도 연구. 미용산업연구, 1: 65-79, 2010. 김곡미. 4차 산업혁명과 글로벌 뷰티시장의 변화에 관한 연구. 상품문화디자인학연구, 50: 221-231, 2017. 김명숙. 피부관리학. 현문사, 서울, pp137-146, 2003.

김문주. 병원 내 피부미용사의 직무 스트레스와 대 고객 서비스 관련 요인. 아시안뷰티화장품학술지, 17: 157-168, 2019.

김진아, 오윤경. 온라인전용 브랜드 화장품의 구매행태와 만족도. 아시안뷰티화장품학술지, $16: 32-41,2018$. 김혜련, 이인희. 'NCS'의 '용사(피부)교육훈련과정'이 '전문성' 및 '실무능력'에 미치는 영향에 관한 연구. 한국산학기술학회 논문지, 15: 3512-3523, 2014.

서정호. 소비자가치기준 변화에 따른 디자인 전략에 관한 연구. 산업디자인학연구, 6: 39-50, 2012.

손효정, 유선희, 박초희. 소비자의 화장품 정보탐색행동과 만족도 및 추천의도의 관계 연구. 아시안뷰티화장품학술지, 17 :

499-509, 2019.

심예진, 최정순. 4차 산업혁명에 따른 뷰티 산업의 발전 방향성에 관한 연구. 한국네일미용학회지, 5: 29-35, 2017. 이정란, 홍해숙. 성인여성의 건강증진 행위에 따른 안면피부 상태. 대한기초간호자연과학회지, 2: 20-37, 2002. 이지현, 윤천성. 피부(미용)국가자격증 제도 및 문제점에 대한 개선방안 연구. 뷰티산업연구, 4: 5-28, 2010. 
정선희. 미용사(피부) 국가자격증과 국제자격증 $\mathrm{CIDESCO,} \mathrm{ITEC}$ 의 비교 분석 및 개선방안. 대한미용학회지, 8: 67-73, 2012.

차의진, 안홍석. 한국과 독일 및 영국의 피부미용사 국가자격증 제도의 비교연구. 대한피부미용학회지, 9: 141-151, 2011.

최경임. 연령대별 피부고민 분석 및 맞춤화장품에 관한 연구. 한국메이크업디자인학회지, 12: 15-29, 2016. 


\section{中文摘要}

\section{化妆品制剂管理人员国家资格考试制度的改善方向性的研究}

洪池柔 ${ }^{1}$, 金永三 $^{2 \star}$

建国大学化妆品工学科, 首尔, 韩国

2建国大学产业大学院影像产业学科, 首尔, 韩国

目的: 探讨定制化的化妆品制剂管理人员与美容师之间的关系, 并提出提高现行定制化的化妆品制剂管理人员国 家资格考试制度有效性的方法。方法: 该调查包括131位已获得或计划获得定制化的化妆品准备经理执照的美容 师。使用SPSS（社会科学统计软件包）V.18分析数据。结果：皮肤美容师通常对为定制的化妆品制剂经理引入 国家资格考试感到满意, 但在没有性能测试, 没有考试资格限制, 甚至没有教育系统下, 如何评价实践能力等 对考试的管理方式并不完全满意。此外, 他们对当前的课程总体不满意, 对课程中指定的定制化妆品制剂管理 者的职责范围和技能的明确标准不清楚, 并且课程中没有提供实际实践的课程, 尽管他们应该成为一个。结论: 除了制定处方化妆品定制工作技能标准外, 还需要改进目前针对化妆品定制管理人员的资格考试的考试课程和 方法。建立该体系的这一努力将为定制的化妆品制剂管理者建立社会信任，提高许可证的有效价值，并为定制 的化妆品企业在我们的社会中建立奠定基础。

关键词: 定制的化妆品制剂管理人员，美容师，工作相关性，国家资格考试系统，系统改进 